\title{
Understanding of African Philosophy Through Philosophy for Children (P4C)
}

\author{
Matsephe M. Letseka \\ College of Education, University of South Africa \\ E-mail: letsemm@unisa.ac.za
}

\author{
Doi:10.5901/mjss.2013.v4n14p745
}

\begin{abstract}
The trend among philosophy of education student teachers at the University of South Africa (UNISA) is a poor grasp of the underlying assumptions and principles of African philosophy, or what British social historian E. P.Thompson (1995) called 'the poverty of theory'. In this paper I attempt to centre the study of African philosophy in the teacher education curriculum at UNISA. The paper explores the potential for interfaces between critical thinking, philosophy for children (P4C) and African philosophy, in particular the worldview of ubuntu and communalism. The paper grows out of my concern as teacher educator about South African student teachers' poor immersion in the African philosophical frameworks that ought to inform their practice. Since the transition from apartheid to democracy in 1994 South Africa's Department of Education has placed a heavy premium on the promotion of African values such as ubuntu (human dignity) and communalism in its policies. That said studies in education show that these imperatives only remain at policy level and scholarly discussions, and are not reflected in the actual practice of teaching and learning. This paper explores ways in which philosophy of education students can be supported to develop a grasp of African philosophy, with emphasis on ubuntu and communalism. Second, my assumption is that P4C has the potential to induct school children in the appreciation and enjoyment of philosophical debates and engagement, which is the cornerstone of university teaching and learning.
\end{abstract}

Keywords: philosophy for children (P4C); African philosophy; ubuntu; critical thinking

\section{Introduction}

This paper arises from the findings of my Doctoral research on the perceptions of Philosophy of education students on African philosophy. ${ }^{1}$ The study, which revealed that the trend among philosophy of education student teachers at the University of South Africa (UNISA) is a poor grasp of the underlying assumptions and principles of African philosophy, analysed the students' written responses to assignment questions on African philosophy. The student responses showed that the majority tend to conflate African philosophy with ubuntu; African philosophy with the traditions and cultural practices of African people, and a misplaced belief that African philosophy lacks reason and rationality, which are the characteristic features of critical thinking. These misconceptions emanate from three factors: first, the students' lack of critical thinking skills, which leads them to uncritically accept the information they read in their study materials, including their prescribed text book. Second, while I note that undergraduate students lack critical thinking skills, I acknowledge that it is not entirely their fault. Most students come from a schooling system that does not sufficiently prepare students for the rigours of university teaching and learning (Slonimsky \& Shalem, 2006; Boughey, 2005; Nyamapfene and Letseka, 1995). Furthermore, the prescribed textbook, tutorial letters and the discussion class notes that students use as learning material perpetuate some of the students' misconceptions about African philosophy. Finally. the open and distance learning (ODL) environment in which UNISA students study is not amenable to the acquisition and application of critical thinking skills.

What I set out to do in this paper is to explore ways in which philosophy of education students at the University of South Africa (UNISA) can be supported to develop a grasp of African philosophy. I shall make some recommendations on how to deal with the challenge of students' lack of critical thinking skills by advocating the introduction of philosophy for children (P4C) at school level. It is my contention that introducing the study of philosophy at school level has the potential to foster critical thinking, philosophical thinking and argumentation in learners as early as possible and to equip them with the skill to regard and engage in such discourses as 'second nature'. I am persuaded that the introduction of philosophy for children (P4C) in schools can be a useful initiative for inserting the culture of critical thinking in school

${ }^{1}$ See Letseka, M.M. (2012) "An analysis of undergraduate philosophy of education students' perception of African philosophy", unpublished DEd thesis, College of Education, University of South Africa, Pretoria, South Africa. 
classrooms as 'communities of inquiry'. ${ }^{2}$ The community of inquiry in P4C "invites children to critically question the ideas around them; and to take each other as seriously as they wish to be taken; to forward new ideas of their own and to support each other in building common understanding" (Ndofirepi, 2011:250).

The paper proceeds as follows. First, I delineate the underlying assumptions of African philosophy, from the seminal works of Kenyan philosopher and theologian John S. Mbiti $(1989,1975)$, to Odera Oruka's $(2002,1990)$ demarcation of African philosophy into the four trends and his authoritative assertion of sagacity's orientation as critical, dialectical and philosophical. Second, I touch on the notion of ubuntu as it applies mostly to Southern Africa. I argue that much as ubuntu is an important concept that articulates and animates African communal interdependence there is a worrying tendency among African philosophy and philosophy of education students at UNISA to conflate ubuntu with African philosophy, when in fact ubuntu is a worldview within African philosophy. Following on the acknowledgement of sage philosophy as a critical pursuit in its own right within traditional African communities, in the third section I briefly tease out the notion of critical thinking and highlight its importance to teaching and learning. I follow this with an exploration of philosophy for children (P4C) which I argue has the potential to equip children with the skills of philosophising, which are necessary for university teaching and learning. In the penultimate section I weave the forgoing sections together to show how they complement each other. I close off with some concluding remarks.

\section{African Philosophy}

Kenyan philosopher and theologian John S. Mbiti's seminal works African Religions and Philosophy (1989) and Introduction to African Religions (1975) provide a useful starting point for articulating African philosophy. Mbiti (1969:108109) argues that African societies are characterised by communal interdependence. The latter is premised on the existence and flourishing of the extended family. It is Mbiti's (1975:176) contention that in traditional African livelihood an individual lives in or is part of a family, that is, the extended family. It is his view that "the extended family is a microcosm of the wider society. It presupposes a broad spectrum of associations including children, parents, grandparents, uncles, aunts, cousins, nieces, and other distant relatives". In the same vein Ghanaian anthropologist Eric Ayisi (1992:16) contends that the extended family "forms the raison d'être of all social co-operation and responsibility. It acts as a social security for the members of the group". Similarly, Gyekye (1997:292-293) notes that "one outstanding cultural value of the traditional African society that is a feature of ever-present consciousness of ties of kinship is the emphasis on the importance of the family - the extended family". In a recent publication Letseka (2013) draws on American liberal feminist political philosopher Susan Moller Okin's (1989) book Justice, Gender, and the Family to argue that the family is "a school of justice".

Kenyan philosopher Henry Odera Oruka is credited for formulating the four trends of African philosophy and for introducing the notion of philosophic sagacity. The four trends of African philosophy introduced by Oruka are: ethnophilosophy, philosophic sagacity, nationalist-ideological philosophy and professional philosophy. These trends are significant in that they illustrate that there is more to African philosophy than traditions and cultures or even a worldviews such as ubuntu. Let me briefly elaborate of each of these trends. Oruka (2002:120-124) argues that ethno-philosophy is embodied in communal African customs, poems, taboos, religions, songs, and dances, the result being that African philosophy is identified with communal or 'folk philosophy'. Ethno-philosophy implies that the community can philosophise, which according to Oruka is denied by Plato's maxim that multitudes cannot philosophise. Oruka (2002:121) contends that the greatest shortcoming of ethno-philosophy is that "it is not derived from the critical but the uncritical part of African tradition" such as "beliefs and activities of the type found in religions, legends, folk tales, myths, customs, superstitions".

The second trend of African philosophy according to Oruka is philosophic sagacity. This is the philosophy practised by indigenous thinkers or sages; people who have not had the benefit of modern education but are considered critical independent thinkers who are capable of using their own thought and judgements based on the power of reason and inborn insight rather than the authority of the communal consensus (Oruka, 2002:121). This suggests that "Africans, even without outside influence, are not innocent of logical and dialectical critical inquiry; that literacy is not a necessary condition for philosophical reflection and exposition" (Oruka, 2002:121). Thus philosophic sagacity can be individualistic,

\footnotetext{
2 See Wenger, E. C. (1998) Communities of Practice: Learning, Meaning, and Identity, Cambridge University Press: Cambridge; Wenger, E. C. (2000) "Communities of Practice and Social Learning Systems", Organisation, 7(2), 225-246; Wenger, E. C., \& Snyder, W. M. (2000) "Communities of practice: the organisational frontier", Harvard Business Review, January-February, 139-145; Wenger, E. C. (2003) "Communities of practice and learning as a social system", in Davide Nocolini., Silvia Gheradi., \& Dvora Yanow (eds) Knowing in Organisations, M. E. Sharp, Inc: New York, 76-99
} 
dialectical, rigorous and philosophical in the western sense (Oruka, 2002:122). Oruka (2002:122) contends that notwithstanding evidence that the sages for his study were mainly found in Kenya, it is reasonable to infer that the sages can be found all over Africa. According to Ochieng'-Odhiambo (2002:22), philosophic sagacity "is a philosophy in traditional Africa that avoids falling into the pitfall of ethno-philosophy in spite of the latter being a major trend in African philosophy". Drawing on Oruka, Ochieng'-Odhiambo (2002:22) defines philosophic sagacity as "the critical reflective thought of sages. It differs fundamentally from ethno-philosophy in that it is both individualistic and dialectical: It is a thought or reflection of various known or named individual thinkers not a folk philosophy and, unlike the latter, it is rigorous and philosophical in the strict sense". Although philosophic sagacity may not be the same as the conventional, long-winded philosophical arguments, "most of it is explicitly expressed in enthymematic form ... a short-cut logical or philosophic argument in the exact sense of philosophy" (Oruka, 2002:122).

The advocates of nationalist-ideological philosophy are of the view that African philosophy must be different from such Western philosophies as capitalism, socialism or communism (Higgs \& Smith 2006b:46). They argue that a peculiarly African philosophy should embrace communalism as one of its basic tenets (Oruka, 2002). Nationalistideological philosophy is practised by most African nationalist leaders and statesmen, for instance, Amilcar Cabral of Guinea Bissau, Kwame Nkrumah of Ghana, Kenneth Kaunda of Zambia, Steve Biko of South Africa and Julius Nyerere of Tanzania (Higgs and Smith, 2006a:91). Their contributions to this trend are not strictly philosophical, and yet they differ from ethno-philosophy in that they do not "assume or imply that European thought or philosophy is radically different from or irrelevant to African thought. Secondly, the authors do not give the impression that the philosophy they are expounding is not theirs, but of a whole African community or continent" (Oruka, 2002:122). Even though nationalist-ideological philosophy may be rooted in traditional or communal Africa, it is evident that it reflects the cultural philosophical orientations of its author. Unlike ethno-philosophy, which appears to consist of "apolitical and free-for-all-metaphysics", nationalist-ideological philosophy is practical and has explicit national and individual problems to solve (Oruka, 2002:122).

Professional philosophy is practised by professional philosophers who are trained in western philosophy and conceive philosophy as a universal discipline whose meaning cannot depend only on racial or regional make-up (Higgs \& Smith, 2006a:91). Most of this philosophy rejects the assumptions of ethno-philosophy (Oruka, 2002:123). According to this trend, philosophy involves critical, reflective and logical inquiry, that is, philosophy in the western sense. This would include "all what has been produced or can be produced by African thinkers or in the African intellectual context in any branch of philosophical thought in the strict sense" (Oruka, 2002:123). This trend in African philosophy has been criticised for being Western not African. However, some African philosophers claim that Greek philosophy actually originates from Egypt, which is part of Africa; as such, Africa does have a share in modern philosophy (Oruka, 2002:123; Okafor, 1997:252 citing George G. M. James 1954). Some philosophers like Bodunrin (1981:178) are of the view that professional philosophy should be the only recognised form of philosophy and should not be seen to belong to particular cultures or traditions. This philosophy can be appropriated by any culture, including African cultures. For instance, one of the most prominent British philosophers Bradley, is a Hegelian; Hegel himself being German. I should hasten to mention that British philosophy was largely influenced by the "Greek thought (itself informed by early Egyptian thought), continental idealism, and scientific philosophy (the philosophy of the Vienna Circle). These philosophers believed that the historical law of intellectual development dictates that "intellectual offerings in a given culture are appropriated and cultivated in other cultures" (Oruka, 2002:123).

To briefly summarise, what I attempted to do in this section is to delineate the contours of African philosophy by sketching Oruka's four trends in African philosophy. These are ethno-philosophy, philosophical sagacity, nationalistideological philosophy, and professional philosophy. I underscored that even with its communal African setting sage philosophy can be individualistic dialectical, rigorous and critical. In the next section I explore the notions of ubuntu, communalism and interdependence as characteristic features of African philosophy.

\section{Ubuntu}

In most African countries African philosophy is associated with the principles of ubuntu, communalism and Indigenous Knowledge Systems (IKS). Ubuntu, is neatly captured by the expression umuntu ngumuntu ngabantu (in Nguni languages of Southern Africa), or motho ke motho ka batho (in Sotho languages). The English translation of this expression is "a person is a person by association with other persons". Ubuntu is a way of life, or a worldview which sustains the wellbeing of a 'people', community or society. Even though ubuntu is often regarded as a purely South African concept, in reality it is not. Every 'people' or community displays its own version of ubuntu (Sindane and 
Liebenberg, 2000:38). For instance, in Southern Africa there are different variations of ubuntu based on the different linguistic variations. it is umunthu in Chewa, umundu in Yao, bunhu in Tsonga, unhu in Shona, botho in Sotho or Tswana, vhutu in Venda and ubuntu in Xhosa and Ndebele" (Tambulasi and Kayuni, 2005: 148). In some European cultures, for instance in German philosophy, the notion of Bildung refers to the cultivation of a person's humanity (Biesta, 2002:378). Others have suggested that the principal aim of Bildung is to strengthen the person's innate powers and character development (Løvlie \& Standish, 2002:318).

Broodryk (2002:13) defines ubuntu as a comprehensive ancient African worldview based on the values of intense humanness, caring, sharing, respect, compassion and associated values. In the same vein Letseka (2000:180) argues that ubuntu has normative implications in that it encapsulates moral norms and values such as "altruism, kindness, generosity, compassion, benevolence, courtesy, and respect and concern for others". There is a link between the communal interdependence characteristic of African communities and the notion of ubuntu. Communal interdependence among the Southern Sotho people, for instance, involved cooperative community farming or letsema [in Sesotho language], whereby four or more families would come together and agree on a duty roster that would allow them to cultivate each other's fields to make them ready for planting (Letseka, 2000:183). In the same way that ubuntu has a link with communal interdependence; it also has a link with the value of tolerance.

Ubuntu is also linked with communality or communalism, that is, the sense of community and communal interdependence. Writing with Kenya in mind Mbiti is credited for connecting African communities with the notion of community with his most cited maxim: "I am, because we are; and since we are, therefore I am". Mbiti (1989:108-109) writes that within this logic, "whatever happens to the individual happens to the whole group, and whatever happens to the whole group happens to the individual". Former Kenyan president Jomo Kenyatta (1965:297) made the following remarks on the traditional life and ways of thinking of the Gikuyu people of Kenya: "nobody is an isolated individual. Or rather, his uniqueness is a secondary fact about him; first and foremost he is several people's relatives and several people's contemporary". Citing Boykin et al (1995), Venter (2004:151) argues that communalism as an awareness of the fundamental interdependence of people whereby duty to one's social group is more important than individual rights and privileges. Ghanaian philosopher Kwame Gyekye (1987:155) defines communalism in African societies as the doctrine whereby the group becomes the focus of the individuals' activities. This doctrine places emphasis on the success of the wider society though not at the expense of the individual.

Another scholar who explores the importance of community in African life is UNISA philosopher of education Moeketsi Letseka (2000). Letseka (2000:181) emphasises that belonging to the community constitutes the very fabric of African life. He points out that African communities are unlike the West which takes the individual as some sort of entity that is capable of existing and flourishing on its own, unconnected to any community of other individuals; not bound by any biological relationships or socioeconomic, political and cultural relationships, obligations, duties, responsibilities and conventions that frame and define any community of individuals. For Letseka, (2000:182), communalism is a very important component of African philosophy. It is his contention that African philosophy should speculate about the communality of the individual in the African setting. It should provide conceptual frameworks for interpreting and analysing the humaneness that botho or ubuntu capture. It should provide rational tools for critical reflections on personal wellbeing or human flourishing, on communal ethics and how these ought to impact on human conduct.

How then do all these views and contentions play themselves out with reference to education, in particular, African philosophy of education? The above views and contentions indicate that ubuntu, which is part of ethno-philosophy, is an important part of African philosophy. However, it is important that students of African philosophy of education should move beyond the particular, that is, away from focussing only on ubuntu or traditions and culture when discussing African philosophy. Instead, they should embrace all aspects of African philosophy as emphasised in Oruka's sketching of the trends in African philosophy. My view is that African philosophy of education students should be taught and encouraged to be critical, innovative and reflexive instead of merely accepting African traditions and cultures as the only way of projecting African philosophy. Drawing on Wiredu's (2004:17) qualities of an educated person, Waghid (2004:57) emphasises that students of African philosophy should be reasonable. They should be able to articulate clear, logical and defensible arguments, and strive to find out how or why certain traditions and customs came about and what their significance was or still is, instead of dismissing them as barbaric or illogical. In other words, students of African philosophy should develop sound critical thinking skills.

To briefly summarise, in this section I explored ubuntu as a characteristic feature of traditional African communal interdependence. I showed that students of African philosophy of education tend to conflate ubuntu or traditions and cultures of the African peoples with African philosophy. I argued instead that African philosophy should be explained in terms of Oruka's four trends. The next section briefly explores the concept of critical thinking with a 
view to showing how it has the potential to enable students to develop a deeper, more nuanced understanding of African philosophy.

\section{Critical thinking}

Critical thinking is regarded as one of the most important outcomes of most learning processes, which should be instilled at school level. Essentially it entails judging the authenticity, worth or accuracy of something; that is, it is essentially evaluative. It involves precise, persistent and objective analysis of any claim, source or belief to judge its accuracy, validity or worth (Letseka \& Venter, 2012). Beyers (1988:62) argue that probably the most all-inclusive act of critical thinking is that of argumentation - argument making and argument analysing. An argument, in critical thinking terms, is an assertion or claim accompanied by a line of reasoning that supports this claim and that denies any alternative claim. Letseka \& Zireva (2013) draw on John Dewey's book How We Think to unpack the notions of 'thinking', 'reflective thinking', and 'critical thinking', and to underscore these concepts' importance to teaching and learning. They argue that "thought denotes belief resting upon some basis, that is, real or supposed knowledge going beyond what is directly present. It is marked by acceptance or rejection of something as reasonably probable or improbable" (Letseka and Zireva, 2013: 52). It is their view that "in educational practice a hermeneutic approach has to be advocated mainly to foster 'critical thinking' (Letseka and Zireva, 2013: 53). They are persuaded that "critical thinking is perhaps the most important skill a student can learn in school and college" because critical thinking is associated with "philosophical inquiry. Drawing on the work of Sue Knight and Carol Collins (2010) on 'the power of philosophical inquiry', Letseka and Zireva (2013: 58) define philosophical inquiry as "the questioning of underlying assumptions, assumptions whose truth or falsity cannot be decided by appeal to experiment and observation".

It is my contention that the infusion of critical thinking at school level is necessary to enable the learners to cope with the demands of higher education teaching and learning which require one to think "on their feet", take a stance and make clear, rational choices and decisions. The acquisition of critical thinking skills from as early as the schooling level has the potential to equip African philosophy students with the skills to understand, recognise and challenge some of the misconceptions about African philosophy. As alluded to in the introduction, current students of philosophy of education at UNISA are not able to conceptualise African philosophy. This can be attributed to their lack of critical thinking skills. This has serious implications in that the students are not able to read their prescribed books critically and for the purpose of deeper understanding. Instead they tend to accept the assumptions of what they read as unproblematic, and even uncontroversial. One of the most important issues about critical thinking is that it is perceived to be the epitome of good thinking (Egege \& Kutieleh, 2004: 79). However, I must hasten to caution that what may be regarded as good thinking in one culture may not necessarily be so in another. Invariably the label 'critical thinking' emerges from Western philosophy, which is different from other philosophies. But as I argued in section on African philosophy above, there are semblances of critical thinking in African philosophy as highlighted by the role of the sages, who hold critical views on societal cultures and traditions even without formal western schooling.

To summarise, what I have attempted to do in this section is to briefly tease out the nuances of critical thinking and to highlight its importance to teaching and learning. I therefore want to argue a case for introducing the students of African philosophy to philosophical inquiry and critical thinking early in their learning careers in order to equip them with the skills of critical scrutiny and analysis. I do believe that this induction into philosophical dispositions should start at schooling level. In the section that follows I explore the potential of philosophy for children (P4C) for critical thinking skills.

\section{Philosophy for children (P4C)}

In the 1970s philosophers such as Matthew Lipman and Margaret Sharp developed P4C as a way of introducing children to philosophising and thinking critically at an early age. These philosophers based their work on the theories of Russian psychologist Lev Vygotsky. For instance, Roberts (2006:12) contends that Vygotsky considered learning through instruction rather than age as a fundamental feature of human intelligence. Vygotsky's theory highlighted the role played by adults (teachers, parents, educators), peers and others in fostering and enhancing cognitive development in children, through communication, language and social interaction (Roberts, 2006:12). He emphasised "the existence of lower and higher mental functions in learning. Lower mental functions are culture free and stay more or less the same through the ages - it is part of the biological heritage of human beings. The higher mental functions, however, develop through a specific human being's lifespan and are a result of interaction with other human beings and the mastering of cultural tools in cooperation with others" (Letseka \& Venter, 2013: 115). But as I argued, in a collaboration with a research associate, 
"P4C is concerned with cognitive, moral and aesthetic development in the context of shared inquiry into philosophical topics and the practice thereof has been greatly influenced by the works of scholars within the social learning tradition like Vygotsky's" (Letseka \& Venter, 2013: 115).

P4C is meant to integrate "the methods and content of philosophy and pragmatic ideal of community of inquiry in order to facilitate critical, creative, caring, and communal thinking skills, as well as the social skills and attitudes necessary for democratic citizenship" (Bleazby, 2011:453). The community of inquiry has its roots in the times and work of Socrates and claims that "deliberative and collaborative communities are exceptional in their ability to foster critical, creative and caring thinking, leading to sounder reasoning, understanding, and judgement" (Lipman, 1998:278). For P4C then, the classroom becomes such a community of inquiry in which emphasis is placed on "dialogue and reflection, with the class discussion building upon the philosophical issues present in the philosophical novels for children" (Hagaman, 1990:151). Lipman and Sharp were convinced that children can learn philosophy at an early age. They demonstrated that much as the "proper teaching of history generates historical thinking, and the proper teaching of mathematics generates mathematical thinking, and so the proper teaching of philosophy must generate philosophical thinking" (Lipman \& Sharp, 1978:85).

Murris (2000:263) concurs. She argues that primary school children do not study mathematics or history as capably as professional mathematicians or historians, yet there has never been a call for them not to study these subjects. Young children will obviously not engage in philosophical arguments in the same way as adults or professional philosophers, but they have the potential to learn the skills of philosophising from an early age and to engage in such arguments later in their lives. This process can be initiated by encouraging children to ask a simple question: 'why?', and for parents to make a commitment to either respond to the question as lucidly as they can, or to adopt a typical Socratic attitude of offering an alternative probing question to urge the child to reflect further on alternative answers to the initial question he/she might have asked. I endorse Murris's (2000:263) contention that abstract concepts do not just develop but can be taught. By also relying on Vygotsky's theory, Murris argues that training is more important than age in developing philosophical inquiry.

P4C has come under heavy criticism from philosophers who are convinced that philosophical thinking would be too complicated for children. The criticisms stem in part from Piaget's theory on the stages of development which claims that cognitive development is a natural progression and has clearly definable stages (Lyle, 2000:46). Roberts (2006:8) lucidly summarises Piaget's cognitive development stages as follows:

Piaget emphasised that children pass through a series of four cognitive developmental stages before they construct the ability to perceive, reason and understand in mature and rational ways. The sensorimotor stage (birth to 2 years) is characterised by behaviour that is goal-directed, with goals moving from concrete to abstract. The preoperational stage (2 to 7 years) is characterised by the acquisition of semiotic functioning and the engagement in symbolic and language games, and a difficulty in seeing another person's point of view and where thought and communication are egocentric. The concrete operational stage (7 to 11 years) is characterised by the performance of true mental operations and solving of concrete problems in a logical fashion, and a difficulty in thinking hypothetically and in systematically considering all aspects of a problem

One of the most prominent implications of Piaget's theory is that "children have to reach a particular cognitive developmental stage to be able to reason about abstract matters and think philosophically" (Roberts, 2006:10). However Piaget's argument that children under 7 years are at a pre-logical stage and cannot engage in formal operations was challenged by Lipman, who argued that philosophically, children are likely to ask more interesting questions than adults (Vansieleghem \& Kennedy, 2011:175). My own view is that P4C can be an invaluable tool for teaching children to philosophise: to "define common concepts more clearly, learn how to question, how to reason, and how to articulate their ideas and subject them to examination" (Lyle, 2000:58). In a community of inquiry, children learn to "aim at common objectives, share ideas and information with each other, and try to be impartial and objective in their mutual criticism" (Daniel \& Auriac, 2011:422). Daniel \& Auriac further show that in a community of inquiry children also learn to be tolerant towards each other by showing interest in one another's beliefs and interests and to respect one another's differences of perspective. For Sharp (1987:39), a community of inquiry "allows children to perceive the other's point of view and to take it into account in constructing their own world view".

The question that needs to be asked at this stage is: Are there alternative ways of teaching critical thinking in schools today besides through P4C? This question can be answered by determining the kinds, and complexity of skills that constitute critical thinking skills. In the foregoing analysis I have already alluded to the fact that in order for one to 
acquire critical thinking skills, one must possess both dispositions and abilities to be critical. These dispositions and abilities are a craft into which one must be apprenticed through a rigorous and critical pedagogy.

To briefly summarise, I have made a case for philosophy for children (P4C), arguing that notwithstanding the challenge from some philosophers, P4C has the potential to equip children with the skills to philosophise. These skills become necessary when children graduate from school to university where most learning is premised on possession of critical and philosophical skills. The next section explores what skills constitute critical thinking skills and looks into other ways in which critical thinking skills might be taught in schools.

\section{African philosophy, critical thinking and P4C}

In the foregoing sections I have argued that undergraduate students of Philosophy of Education tend to conflate African philosophy with ubuntu and traditions and cultural practices of the African people. The students also claim that African philosophy does not encourage critical thinking. In this final section I attempt to find common threads between African philosophy, critical thinking and P4C. In my doctoral study [see footnote 1 above] I argued that the students' conflation of African philosophy arose from the students' study materials. I argued that the students lacked critical thinking skills and ability to critically engage with their study materials. In the section on African philosophy above, I underscored that African philosophy does not only consist of ubuntu, and traditions or cultural practices of the African people. I drew on Oruka's formulation of the four trends of African philosophy to argue that African philosophy can be categorised into ethno-philosophy, philosophic sagacity (sage philosophy), professional philosophy and nationalist philosophy. The literature highlights that it is incorrect to suggest that African philosophy does not encourage critical thinking given that philosophic sagacity is the philosophy practised by wise African people [sages] who think critically and are capable of challenging authority (Oruka, 2002, 1990; Ochieng-Odhiambo, 2002; Higgs \& Smith, 2006a, 2006b).

Literature on critical thinking in South Africa suggests that most first year university students are not adequately prepared for university teaching and learning (Letseka., Bantwini., \& King-McKenzie, 2012; Boughey, 2005; Nyamapfene \& Letseka, 1995). For instance, Letseka., Bantwini., \& King-McKenzie (2012: 1201) cite Slonimsky \& Shalem (2006) to highlight the fact that normally students who matriculate are expected to be highly practiced in working on text-based realities and creating their own text-based realities through writing. But a significant proportion of students currently enrolling in higher education do not appear to have mastered properties of text based realities. They tend to follow a series of pervasive patterns in their approach to texts and epistemic practices when they first engage in university study-verbatim reproduction or plagiarism; a tendency to focus on examples rather than on principles; a tendency to write from a highly subjective viewpoint without depersonalizing; a failure to pull out arguments in text or cast them; a tendency to include anecdotes as a justification for claims, and a tendency to be prescriptive or normative when asked to be analytic.

The findings of my own doctoral study confirmed that this can be attributed to the students' lack of critical thinking skills. The study also confirmed that the study materials, such as the prescribed textbook, the study guide, the tutorial letters and the lecture notes used during discussion classes perpetuate this lack of critical thinking skills and the subsequent conflation of African philosophy. Perhaps another significant consideration could be that the open distance learning (ODL) environment of UNISA might not be conducive to the acquisition of critical thinking skills and the subsequent application of such skills given ODL's poor throughput rates (Letseka \& Pitsoe, 2012).

Critical thinking permeates most South African education policy statements since the advent of democracy in 1994. The latest of the policy documents, The National Curriculum Statement Grade R-12 (2011) aims to encourage "an active and critical approach to learning, rather than rote and uncritical learning of given truths" DBE (2011:4). While I am cognisant of the challenges that might arise from the different understandings of Piaget's stages of development, it is my contention that the introduction of P4C in the school curriculum can be a useful policy intervention for introducing children to critical thinking skills within the community of inquiry that the classroom is. The community of inquiry in P4C "invites children to critically question the ideas around them; and to take each other as seriously as they wish to be taken; to forward new ideas of their own and to support each other in building common understanding" (Ndofirepi, 2011:250). Being able to think critically could in turn enable students to critique the learning materials and information they receive about African philosophy.

The similarity between P4C's community of inquiry and African philosophy's communal interdependence are unmistakable. For instance, in a community of inquiry learners learn to work together, listen to and care for each other. Similar interactive requirements also pertain to African philosophy. Mbiti (1989:108-109), Ayisi (1992:16) and Gyekye (1997:292-293) have each argued that community and communal interdependence are integral in African societies. For 
Ndofirepi (2011:248), "philosophy for children in Africa will involve a great deal of African philosophical thought, knowledge and wisdom". It is his view that P4C "facilitates the development of autonomous, independent students who also recognise their interdependence and interconnectedness with others" (Ndofirepi (2011:250). Robinson (1995:8-9) argues that philosophy is about the whole person, not just about the techniques; it is about values; and about how we treat others. Thus philosophy enables young people to think critically about values as well as to learn how to be reasonable in their communal life because learning involves community. Most of the successes in human endeavours have occurred through "shared experiences (experiments) of multitude of inquirers and by the productive clash of viewpoints" (Robinson 1995:9-10). From the discussions above the close relationship between P4C, through the community of inquiry, and some of the principles of African philosophy such as ubuntu and communalism is evident.

\section{Conclusion}

The central argument of the paper is that the skills of critical thinking, which are necessary for grasping the deeper nuances of African philosophy, are a craft. And like all crafts, their mastery is dependent on a well structured apprenticeship. In the case of philosophy of education students at UNISA I argued that a deeper grounding in African philosophy can be achieved by introducing philosophy for children (P4C) at school level. This would enable children to begin to dabble with philosophical discourses at an early age. The need for P4C is inspired by the tendency among philosophy of education and African philosophy student's lack of critical thinking skills and the tendency to conflate African philosophy with a worldview such as ubuntu. I drew on the work of Kenyan philosopher Odera Oruka who conducted extensive research among rural communities in Kenya and developed four trends that he argued characterised African philosophy. These are ethno-philosophy, philosophical sagacity, nationalist-ideological philosophy, and professional philosophy. Contrary to UNISA students' conflation, Oruka shows that even within a communal Africa setting sage philosophy can be individualistic dialectical, rigorous and critical, and therefore philosophical.

There is no doubt that critical thinking is important to teaching and learning, and that introducing the students of African philosophy to critical thinking and philosophical inquiry and early in their learning careers cannot be overestimated. The reason for this is that the skills of critical scrutiny and analysis are essential for university teaching and learning. And with research in higher education showing that most students enrolling in higher education do not appear to have mastered properties of text based realities, while most university teaching and learning is premised on possession of critical and philosophical skills, the imperative to introduce P4C at school level becomes an urgent policy imperative.

\section{References}

Ayisi, E. O. (1992) An Introduction to the Study of African Culture, East African Education Publishers: Nairobi.

Beyers, B.K. (1988) Developing a Thinking Skills Program, Allyn \& Bacon, Inc: Boston.

Bleazby, J. (2011) "Overcoming relativism and absolutism: Dewey's ideals of truth and meaning in philosophy for children", Educational Philosophy and Theory. 43 (5), 453-466.

Bodunrin, P. O. (1981) "The question of African Philosophy", Philosophy, 56 (216):161-179.

Boughey, C. (2005) "Epistemological access to the university: an alternative perspective", South African Journal of Higher Education, 19 (3), 638-650.

Broodryk, J. (2002) Ubuntu: Life Lessons from Africa, Ubuntu School of Philosophy: Pretoria.

Daniel, M-F. \& Auriac, E. (2011) « Philosophy, critical thinking and philosophy for children", Educational Philosophy and Theory, 43 (5), 415-435.

Department of Basic Education (DBE). (2011) National Curriculum Statement Grades R-12, Department of Education: Pretoria.

Egege, S \& Kutieleh, S. (2004) "Critical thinking: teaching foreign notions to foreign students", International Education Journal, 4 (4), $75-$ 85.

Gyekye, K. (1997) Tradition and Modernity: Philosophical Reflections on the African Experience, Oxford University Press: Oxford.

Hagaman, S. (1990) "The community of inquiry: an approach to collaborative learning.", Studies in Art Education, 31 (3), $149-157$.

Higgs, P \& Smith, J. (2006a) Rethinking Truth, 2nd Edition, Juta: Cape Town.

Higgs, P. \& Smith, J. (2006b) Rethinking our World, 2nd Edition, Juta: Cape Town.

Kenyatta, J. (1965) Facing Mount Kenya, Vintage Books: New York.

Knight, S., \& Collins, C. (2010) Enlivening the curriculum: The power of philosophical inquiry, Theory and Research in Education, 8(3), 305-318.

Letseka, M. M. \& Venter, E. (2013) "Learning critical thinking skills through philosophy for children (P4C)", in Eldrie Gouws and Charl Wolhuter (eds). Educational Research in South Africa: Practices and Perspectives, SAERA 2013 Conference Proceeding, Oxford University Press: Cape Town. 
Letseka, M.M. (2012) "An analysis of undergraduate philosophy of education students' perception of African philosophy", unpublished DEd thesis, College of Education, University of South Africa, Pretoria, South Africa.

Letseka, M.M. \& Venter, E. (2012) "How student teachers understand African philosophy", Koers - Bulletin for Christian Scholarship $77(1 \& 2), 1-8$

Letseka, M. (2013) "Anchoring ubuntu morally", forthcoming in Mediterranean Journal of Social Sciences, 4 (4), September.

Letseka, M., \& Zireva, D. (2013) "Thinking" lessons from John Dewey's How We Think", Academic Journal of Interdisciplinary Studies, 2 (2), 51-60.

Letseka, M., Bantwini, B., \& King-McKenzie, E. (2012) "Public union sector politics and the crisis of education in South Africa", Creative Education, 3 (7), 1197-1204.

Letseka, M., \& Pitsoe, V. (2012) "Access to higher education through Open Distance Learning (ODL): reflections on the University of South Africa (UNISA)", in Rubby Dhunpath and Renuka Vithal (eds) Access to Higher Education: Under-prepared Students or Under-prepared Institutions?, Pearson: Cape Town.

Letseka, M. (2000) "African philosophy and educational discourse", In African Voices in Education, edited by P. Higgs, N.C.G. Vakalisa, T.V. Mda and N.T. Assie-Lumumba, Landsdowne: Juta, 179-193.

Lipman, M. (1998) "Teaching children to think reasonably: some findings of philosophy for children program", The Clearing House, 71 (5), 277-280.

Lipman, M. \& Sharp, A. M. (1978) "Some educational presuppositions of philosophy for children", Oxford Review of Education, 4 (1), 85 90.

Løvlie, L. \& Standish, P. (2002) "Introduction: Bildung and the idea of a liberal education", Journal of Philosophy of Education, 36 (3), 317-340.

Lyle, S. (2000) "Narrative understanding: developing a theoretical context for understanding how children make meaning in classroom settings", Journal of Curriculum Studies, 32 (1), 45-63.

Mbiti, J. S. (1989) African Religions and Philosophy, Second Edition, Doubleday: New York.

Mbiti, J. S. (1975) Introduction to African Religion, Heinemann: London.

Murris, K. (2000) "Can children learn philosophy?", Journal of Philosophy of Education, 34(2), 261-279.

Ndofirepi, A. P. (2011) "Philosophy for children: the quest for an African perspective", South African Journal of Education, 31:246-256.

Ochieng'-Odhiambo, F. (2002) "The evolution of Sagacity: The three stages of Oruka's philosophy", Philosophia Africana, 5 (1), $19-32$.

Okafor, F. U. (1997) "African philosophy in comparison with Western philosophy", The Journal of Value Inquiry, 31:251-267.

Okin, S. M. (1989) Justice, Gender, and the Family, Basic Books: New York.

Oruka, H. O. (2002) "Four trends in current African philosophy", in Philosophy from Africa, $2^{\text {nd }}$ edition, edited by P.H. Coetzee \& A. P.J. Roux, Oxford University Press: Cape Town, 120-124.

Oruka, H. O. (1990) Sage Philosophy: Indigenous thinkers and modern debate on African philosophy, E. J. Bill: Leiden.

Roberts, A. F. (2006) "The Effects of Development Programme Based on Philosophy for Children", unpublished Master's thesis, University of the Western Cape, Cape Town.

Sharp, A. M. (1987) "What is a 'Community of Inquiry'?", Journal of Moral Education, 16 (1), 37-45

Slonimsky, L. \& Shalem, Y. (2006) "Pedagogic responsiveness for academic depth", Journal of Education, 40:35-58.

Tambulasi, R and Kayuni, H. (2005) "Can African feet divorce Western shoes? The case of 'Ubuntu' and democratic good governance in Malawi", Nordic Journal of African Studies, 14 (2), 147-161.

Venter, E. (2004) "The notion of Ubuntu and communalism in African educational discourse", Studies in Philosophy and Education, 23:149-160.

Waghid, Y. (2004) "African philosophy of Education: Implications for teaching and learning", South African Journal of Higher Education, 18 (3), 56-64.

Wenger, E. C. (2003) "Communities of practice and learning as a social system", in Davide Nocolini., Silvia Gheradi., \& Dvora Yanow (eds) Knowing in Organisations, M. E. Sharp, Inc: New York, 76-99

Wenger, E. C. (2000) "Communities of Practice and Social Learning Systems", Organisation, 7(2), 225-246.

Wenger, E. C., \& Snyder, W. M. (2000) "Communities of practice: the organisational frontier", Harvard Business Review, JanuaryFebruary, 139-145.

Wenger, E. C. (1998) Communities of Practice: Learning, Meaning, and Identity, Cambridge University Press: Cambridge.

Wiredu, K. (2004) "Prolegomena to an African philosophy of education", South African Journal of Higher Education, 18 (3), 17-26. 
